\title{
Influence of soil minerals on chromium(VI) reduction by sulfide under anoxic conditions \\ Yeqing Lan ${ }^{1}$, Baolin Deng*2, Chulsung Kim³ and Edward C Thornton ${ }^{4}$
}

Address: ${ }^{1}$ College of Sciences, Nanjing Agricultural University, Nanjing, 210095, China, ${ }^{2}$ Dept. of Civil and Environmental Engineering, University of Missouri-Columbia, Columbia, MO 65211, USA, ${ }^{3}$ Dept. Environmental Science, University of Dubuque, Dubuque, IA 52001, USA and ${ }^{4}$ Field Hydrology and Chemistry Group, Pacific Northwest National Laboratory (PNNL), Richland, Washington 99352, USA

Email: Yeqing Lan - lanyq102@yahoo.com.cn; Baolin Deno* - dengb@missouri.edu; Chulsung Kim - ckim@dbq.edu; Edward C Thornton - ecthornton@earthlink.net

* Corresponding author

Published: 12 April 2007

Geochemical Transactions 2007, 8:4 doi:10.1186/1467-4866-8-4
Received: 22 September 2006

Accepted: 12 April 2007

This article is available from: http://www.geochemicaltransactions.com/content/8/I/4

(C) 2007 Lan et al; licensee BioMed Central Ltd.

This is an Open Access article distributed under the terms of the Creative Commons Attribution License (http://creativecommons.org/licenses/by/2.0), which permits unrestricted use, distribution, and reproduction in any medium, provided the original work is properly cited.

\begin{abstract}
The effects of soil minerals on chromate $\left(\mathrm{Cr}^{\mathrm{VI}} \mathrm{O}_{4}{ }^{2-}\right.$, noted as $\left.\mathrm{Cr}(\mathrm{VI})\right)$ reduction by sulfide were investigated in the $\mathrm{pH}$ range of 7.67 to 9.07 under the anoxic condition. The examined minerals included montmorillonite (Swy-2), illite (IMt-2), kaolinite ( $\mathrm{KGa}-2)$, aluminum oxide $\left(\gamma-\mathrm{Al}_{2} \mathrm{O}_{3}\right)$, titanium oxide $\left(\mathrm{TiO}_{2}, \mathrm{P}-25\right.$, primarily anatase), and silica $\left(\mathrm{SiO}_{2}\right)$. Based on their effects on $\mathrm{Cr}(\mathrm{VI})$ reduction, these minerals were categorized into three groups: (i) minerals catalyzing $\mathrm{Cr}(\mathrm{VI})$ reduction - illite; (ii) minerals with no effect $-\mathrm{Al}_{2} \mathrm{O}_{3}$; and (iii) minerals inhibiting $\mathrm{Cr}(\mathrm{VI})$ reductionkaolinite, montmorillonite, $\mathrm{SiO}_{2}$ and $\mathrm{TiO}_{2}$. The catalysis of illite was attributed primarily to the low concentration of iron solubilized from the mineral, which could accelerate $\mathrm{Cr}(\mathrm{VI})$ reduction by shuttling electrons from sulfide to $\mathrm{Cr}(\mathrm{Vl})$. Additionally, elemental sulfur produced as the primary product of sulfide oxidation could further catalyze $\mathrm{Cr}(\mathrm{VI})$ reduction in the heterogeneous system. Previous studies have shown that adsorption of sulfide onto elemental sulfur nanoparticles could greatly increase sulfide reactivity towards $\mathrm{Cr}(\mathrm{VI})$ reduction. Consequently, the observed rate constant, $k_{\text {obs }}$, increased with increasing amounts of both iron solubilized from illite and elemental sulfur produced during the reaction. The catalysis of iron, however, was found to be blocked by phenanthroline, a strong complexing agent for ferrous iron. In this case, the overall reaction rate at the initial stage of reaction was pseudo first order with respect to $\mathrm{Cr}(\mathrm{VI})$, i.e., the reaction kinetics was similar to that in the homogeneous system, because elemental sulfur exerted no effect at the initial stage prior to accumulation of elemental sulfur nanoparticles. In the suspension of kaolinite, which belonged to group (iii), an inhibitive effect to $\mathrm{Cr}(\mathrm{VI})$ reduction was observed and subsequently examined in more details. The inhibition was due to the sorption of elemental sulfur onto kaolinite, which reduced or completely eliminated the catalytic effect of elemental sulfur, depending on kaolinite concentration. This was consistent with the observation that the catalysis of externally added elemental sulfur $(50 \mu \mathrm{M})$ on $\mathrm{Cr}(\mathrm{VI})$ reduction would disappear with a kaolinite concentration of more than $5.0 \mathrm{~g} / \mathrm{L}$. In kaolinite suspension, the overall reaction rate law was:
\end{abstract}

$$
-\mathrm{d}[\mathrm{Cr}(\mathrm{VI})] / \mathrm{dt}=k_{\mathrm{obs}}\left[\mathrm{H}^{+}\right]^{2}[\mathrm{Cr}(\mathrm{VI})][\mathrm{HS}-]^{0.70}
$$




\section{Background}

Chromium (Cr) pollution is widely concerned throughout the world because of its large magnitude and known adverse health effect [1]. For example, dregs of chromium are produced during manufacturing Cr-containing alloys and salts. These waste materials usually contain a significantly amount of chromium [2], which could be leached out due to water filtration and/or ground water fluctuation. Chromium contamination of soils and water is also caused by improper disposals of Cr-containing waste water and sludges as used for corrosion inhibition and electroplating industries.

When released into the environment, chromium exists mainly as hexavalent chromate $\left(\mathrm{HCrO}_{4}-\mathrm{CrO}_{4}{ }^{2-}\right.$, noted as $\mathrm{Cr}(\mathrm{VI})$ ) and trivalent forms (noted as Cr(III)). Chromium species at different oxidation states show substantially different physical and chemical properties. $\mathrm{Cr}(\mathrm{VI})$ is an oxidant with high solubility and mobility in soils and aquifers, as well as high toxicity to human and ecosystems; whereas $\mathrm{Cr}$ (III) has lower mobility, mostly precipitated as hydroxides or adsorbed onto mineral surfaces. As a result, contamination of $\mathrm{Cr}(\mathrm{VI})$ is often controlled by $\mathrm{Cr}(\mathrm{VI})$ reduction using various reductants, such as zero valent iron[3], ferrous ions [4-11], and organic compounds [12-14]. Most of these studies aimed to reduce $\mathrm{Cr}(\mathrm{VI})$ in the aqueous phase relevant to groundwater remediation by delivering reductants in solid or liquid forms.

For contamination residing in the vadose-zone, mixing a reactive agent in solid form is often difficult to manipulate and using a liquid reductant runs the risk of further spreading the contaminants to previously uncontaminated zones. A new technology, in situ gaseous reduction (ISGR), has therefore been developed by Pacific Northwest National Laboratory by using gaseous hydrogen sulfide $\left(\mathrm{H}_{2} \mathrm{~S}\right)$ as the reductant $[15,16]$. Laboratory experiments showed that over $90 \%$ of $\mathrm{Cr}(\mathrm{VI})$ could be reduced to $\mathrm{Cr}(\mathrm{III})$ in the soils by $\mathrm{H}_{2} \mathrm{~S}$ treatment [16]. A field study at the White Sand Missile Range, New Mexico, USA, also demonstrated over $70 \%$ of $\mathrm{Cr}$ immobilization through its reduction to $\mathrm{Cr}$ (III) [15]. The field demonstration further showed that hydrogen sulfide could be handled safely for field application [17]. Secondary contamination of $\mathrm{H}_{2} \mathrm{~S}$ is not taking place because the residual gas could be consumed by reaction with iron oxides in soils[18]. The ISGR approach has advantages of easy controls of the reductant delivery and cost-effectiveness.

To design and optimize the ISGR system for reductive $\mathrm{Cr}(\mathrm{VI})$ immobilization in soils, the reaction kinetics between $\mathrm{Cr}(\mathrm{VI})$ and $\mathrm{H}_{2} \mathrm{~S}$ in heterogeneous systems must be fully characterized. Kinetics and mechanism of $\mathrm{Cr}(\mathrm{VI})$ reduction by $\mathrm{H}_{2} \mathrm{~S}$ in the aqueous phase have been estab- lished $[19,20]$. The overall reaction was second order, i.e., first order with respect to $\mathrm{Cr}(\mathrm{VI})$ and first order to sulfide. Elemental sulfur was the major product of sulfide oxidation under the anaerobic condition. Lan et al. [21] further demonstrated that elemental sulfur nanoparticles could greatly catalyze $\mathrm{Cr}(\mathrm{VI})$ reduction by sulfide. These aqueous phase processes are relevant to ISGR treatment in the vadose zone because even though the treatment is by gaseous reductant, $\mathrm{Cr}(\mathrm{VI})$ reduction occur in the water film on mineral particle surfaces formed under suitable humidity [22].

Heterogeneous phase $\mathrm{Cr}(\mathrm{VI})$ reduction by other reductants were also widely studied. Eary and Rai [23] observed $\mathrm{Cr}$ (VI) reduction by hematite and biotite over a wide $\mathrm{pH}$ range, and proposed that the dissolution of ferrous iron from solid phases should take place prior to $\mathrm{Cr}(\mathrm{VI})$ reduction, i.e., the reduction occurs in the solution phase rather than at surface sites. Patterson and Fendorf [24] demonstrated that freshly prepared ferrous sulfide reduced $\mathrm{Cr}(\mathrm{VI})$ quite effectively throughout the $\mathrm{pH}$ range of 5.0 to 8.0 and reaction occurred at solid-solution interface. Buerge and Hug[25] showed that the rate of $\mathrm{Cr}(\mathrm{VI})$ reduction by ferrous iron was significantly increased by several minerals including goethite $(\alpha-\mathrm{FeOOH})$, lepidocrocite $(\gamma$ $\mathrm{FeOOH}$ ), montmorillonite (SAz-1), kaolinite (China Clay), and amorphous silica (Aerosil OX50), but not by aluminum oxide (Aluminiumoxid $\mathrm{C}$ ). In another study, minerals, such as aluminum oxide $\left(\gamma-\mathrm{Al}_{2} \mathrm{O}_{3}\right)$, goethite $(\alpha$ $\mathrm{FeOOH})$ and titanium dioxide $\left(\mathrm{TiO}_{2}\right.$, anatase) were found to catalyze $\mathrm{Cr}(\mathrm{VI})$ reduction by $\alpha$-hydroxyl carboxylic acids and their esters, $\alpha$-carbonyl carboxylic acids, and substituted phenols [26,27].

Whether soil minerals will have a major impact on $\mathrm{Cr}(\mathrm{VI})$ reduction by sulfide has not been reported. As part of our effort to better understand the reaction between $\mathrm{Cr}(\mathrm{VI})$ and $S^{2-}$ in soils, this study aims to: (1) investigate the overall effect of various minerals on the reduction of $\mathrm{Cr}(\mathrm{VI})$ by sulfide; (2) examine the role of $\mathrm{Fe}(\mathrm{III}) / \mathrm{Fe}(\mathrm{II})$ as a component of some minerals in catalyzing $\mathrm{Cr}(\mathrm{VI})$ reduction reaction, and (3) investigate the effect of element sulfur on the reaction in the heterogeneous system where elemental sulfur can be adsorbed on the surfaces of minerals. The examined minerals included montmorillonite, illite, kaolinite, aluminum oxide, anatase, and silica, all common soil minerals [28]. Initial reactant concentrations were set at micromolar level for chromate and millimolar level for sulfide to facilitate kinetic data collection, and were also within the concentration range found at the contamination sites [1]. The study was conducted in alkaline conditions with $\mathrm{pH}$ values from 7.7 to 9.1 . The rationale was that the alkaline condition dominated at the Hanford site (Washington State, USA), where the application of ISGR technology was geared to. A recent study showed $\mathrm{pH}$ val- 
ues ranging from 7,71 to 8.11 in some Hanford groundwater samples [29].

\section{Experimental methods Chemicals}

Potassium dichromate, elemental sulfur $\left(\mathrm{S}_{8}\right)$, diphenyl carbazide, and acetone were obtained from Sigma-Aldrich Company; and boric acid, sodium phosphate, sodium hydroxide, sodium sulfide $\left(\mathrm{Na}_{2} \mathrm{~S} \bullet 9 \mathrm{H}_{2} \mathrm{O}\right)$, sulfuric acid, hydrogen chloride, ferrous chloride, and diammonium hydrogen phosphate were from Fisher Scientific. The chemicals were at least ACS reagent grade and used without further purification, except for sodium sulfide crystals that were rinsed with degassed Milli-Q water (with18.2 $\mathrm{M} \Omega$-cm resistivity, Millipore Corp.) to remove the oxidized surface layer. Stock solutions of chromate and sulfide were prepared by Milli-Q water purged thoroughly with high purity nitrogen gas and stored in amber bottles placed in an anaerobic chamber (Models 855-AC, PLASLABS, INC.) prior to use. Stock solution of elemental sulfur was prepared by dispersing $1.0 \mathrm{~g}$ elemental sulfur $\left(\mathrm{S}_{8}\right)$ in $50 \mathrm{ml}$ acetone. When measured amount of elemental sulfur stock solution was added to reaction system (water solution), acetone concentration was always less than $2 \%$ and sulfur colloid formed immediately due to the change in solubility. Glassware was cleaned by soaking in $1 \mathrm{M}$ $\mathrm{HCl}$ for at least $3 \mathrm{hrs}$ and then thoroughly rinsed by water and Milli-Q water.

\section{Minerals}

Montmorillonite (Swy-2), illite (IMt-2), kaolinite (KGa2) used in this study were obtained from the Source Clay Minerals Repository, University of Missouri-Columbia (U.S.A). Aluminum oxide $\left(\gamma-\mathrm{Al}_{2} \mathrm{O}_{3}\right)$, silicon oxide $\left(\mathrm{SiO}_{2}\right)$, and titanium oxide $\left(\mathrm{TiO}_{2}, \mathrm{P}-25\right.$, primarily anatase) were from Degussa Corporation. Point of zero charge (PZC) and BET specific surface area (SSA) of minerals were listed in Table 1.

\section{Experimental procedure}

Experiments were mostly performed in an anaerobic chamber $\left(\mathrm{N}_{2}\right.$, balanced by $\left.10 \% \mathrm{H}_{2}\right)$ with a temperature of

Table I: pH of Point of Zero Charge and BET specific surface area of tested minerals.

\begin{tabular}{lll}
\hline Minerals & $\mathrm{pH}_{\mathrm{PZC}}$ & $\mathrm{SSA}\left(\mathrm{m}^{2} / \mathrm{g}\right)$ \\
\hline Aluminum oxide & $8.9^{\mathrm{a}}$ & $90.1^{\mathrm{a}}$ \\
Silicon oxide & $2.3^{\mathrm{a}}$ & $90.0^{\mathrm{a}}$ \\
Titanium oxide & $6.5^{\mathrm{c}}$ & $40.5^{\mathrm{a}}$ \\
Montmorillonite & $5.9^{\mathrm{d}}$ & $99.0^{\mathrm{d}}$ \\
Kaolinite & $4.5^{-5.0^{\mathrm{b}}}$ & $22.4^{\mathrm{b}}$ \\
Illite & $3.5^{\mathrm{b}}$ & $24.0^{\mathrm{b}}$ \\
\hline
\end{tabular}

Sources: a - Degussa (199I); b - this work; c - Torrents and Stone (I99I); d-Buerge and Hug (1999)
$24.0 \pm 0.5^{\circ} \mathrm{C}$, including experimental setup and chemical analyses. Solution $\mathrm{pH}$ was controlled by $0.10 \mathrm{M}$ borate buffer. No strong electrolyte was used for ionic strength control in this study, since our preliminary experiments indicated that the reaction was independent of ionic strength when it was between 0.0 and $1.0 \mathrm{M}$.

Kinetic experiments examining the effect of various minerals on $\mathrm{Cr}(\mathrm{VI})$ reduction by sulfide at $\mathrm{pH} 7.87$ were started by purging an adequate amount of buffer solution in a $40 \mathrm{ml}$ amber bottle with high purity nitrogen gas for $20 \mathrm{~min}$. The vessel was closed immediately by a screw cap with Teflon/silicon septum to prevent air from getting into the solution again. Then, the buffer solution was transferred into the anaerobic chamber. A selected mineral (as dry power) and $0.80 \mathrm{ml}$ of $1.00 \mathrm{mM} \mathrm{K}_{2} \mathrm{Cr}_{2} \mathrm{O}_{7}$ stock solution were added into the amber bottle and the suspension was mixed for $30 \mathrm{~min}$. This allowed dispersion of mineral particles and hydration equilibration with the buffer solution. An adequate amount of sulfide stock solution was then introduced to initiate the reaction. The final total volume of the suspension was $40 \mathrm{ml}$. The final concentrations of $\mathrm{Cr}(\mathrm{VI})$ and sulfide were $40 \mu \mathrm{M}$ and 800 $\mu \mathrm{M}$, respectively, and the mineral loading was $5.0 \mathrm{~g} / \mathrm{L}$. The suspension was stirred by a magnetic Teflon bar. About 1 $\mathrm{ml}$ of suspension was periodically sampled by a $3 \mathrm{ml}$ plastic syringe and immediately filtered through $0.22 \mu \mathrm{m}$ membrane filter. Then, $0.50 \mathrm{ml}$ filtrate was measured for $\mathrm{Cr}(\mathrm{VI})$ analysis.

The above experiments showed that $\mathrm{Cr}(\mathrm{VI})$ reduction was greatly enhanced in the system with illite, but depressed in the system with kaolinite and several other minerals. We, therefore, conducted more detailed experiments with illite and kaolinite in the $\mathrm{pH}$ range of 7.67 to 9.07 , aiming to understand why the effects were so different. We hypothesized that the enhanced $\mathrm{Cr}(\mathrm{VI})$ reduction in the system with illlite could be due to the trace amount of iron associated with the mineral and/or surface catalysis. Several types of experiment were performed at $\mathrm{pH} 8.27$ to evaluate whether ferrous iron from illite could alter the reaction rate. These included: (i) adding $5.0 \mu \mathrm{M}$ soluble ferrous iron into the homogeneous system; (ii) introducing 0.10 $\mathrm{mM}$ phenanthroline into the illite suspension $30 \mathrm{~min}$ prior to initiation of the reaction; and (iii) adding 0.10 $\mathrm{mM}$ phenanthroline into the homogenous system as a control test. If ferrous iron was important for $\mathrm{Cr}(\mathrm{VI})$ reduction by sulfide, the reaction rate should increase with externally added $\mathrm{Fe}(\mathrm{II})$, but the effect be eliminated by phenanthroline because it could form strong complexes with $\mathrm{Fe}(\mathrm{II})$, hindering electron transfer to $\mathrm{Cr}(\mathrm{VI})$.

Elemental sulfur, the main product of sulfide oxidation by $\mathrm{Cr}(\mathrm{VI})$ in the anoxic system, is also known to accelerate $\mathrm{Cr}(\mathrm{VI})$ reduction in the later stage of the reaction, after ini- 
tiated in the homogeneous system [21]. Experiments were therefore conducted to assess whether elemental sulfur had a similar impact on the reaction in the heterogeneous systems with illite and kaolinite. Stock solution of elemental sulfur was introduced into the reaction system at $50 \mu \mathrm{M}$ final concentration level before the reaction was started.

\section{$\mathrm{Cr}(\mathrm{VI})$ and sulfide adsorption}

The adsorption of $\mathrm{Cr}(\mathrm{VI})$ and sulfide on illite and kaolinite surfaces at $\mathrm{pH} 7.87$ was assessed by monitoring the concentrations of $\mathrm{Cr}(\mathrm{VI})$ and sulfide in filtrates at defined time intervals. The initial concentrations of $\mathrm{Cr}(\mathrm{VI})$ and sulfide were 40 and $800 \mu \mathrm{M}$, respectively.

\section{Adsorbed and dissolved Fe(II)}

The adsorbed and dissolved ferrous iron (Fe(II)) in illite suspension at $\mathrm{pH} 8.27$ were monitored at defined time intervals. At each time point, $3.0 \mathrm{ml}$ suspension was filtered through a $0.22 \mu \mathrm{m}$ membrane, and then $1.0 \mathrm{ml}$ of the filtrate was acidified with $1.0 \mathrm{ml}$ of $0.1 \mathrm{M} \mathrm{HCl}$ and used for analysis of dissolved $\mathrm{Fe}(\mathrm{II})$ following the established ferrozine method [30,31]. To analyze the amount of sorbed $\mathrm{Fe}(\mathrm{II})$, the solids on the membrane were washed with $3 \mathrm{ml}$ Mill-Q water to remove sulfide residual on the solids, and then the solids along with the membrane were transferred into $3.0 \mathrm{ml}$ of $0.5 \mathrm{M} \mathrm{HCl}$ solution and mixed with a magnetic Teflon bar for $20 \mathrm{~min}$ for $\mathrm{Fe}(\mathrm{II})$ desorption. The suspension with desorbed $\mathrm{Fe}(\mathrm{II})$ was filtered with a $0.22 \mu \mathrm{m}$ membrane filter and a $2.0 \mathrm{ml}$ of the filtrate was mixed with $1.8 \mathrm{ml}$ of $0.5 \mathrm{M} \mathrm{NaOH}$ to neutralize excess acid prior to determination of $\mathrm{Fe}(\mathrm{II})$ by ferrozine method.

\section{Analytical Methods}

$\mathrm{Cr}(\mathrm{VI})$ concentration was determined by the diphenylcarbazide colorimetric method, using phosphoric buffer to control $\mathrm{pH}$ for the color development [26,32]. The absorbance was measured in a $1-\mathrm{cm}$ cell at $540 \mathrm{~nm}$ on a spectrophotometer (Spectronic 20 Genesys, Spectronic Instruments). The method detection limit was approximately $0.05 \mu \mathrm{M}$ and the precision was $5 \%$ rsd. Sulfide concentration in the stock solution was measured with the standard iodometric titration method [32]. Sulfide concentration during the reaction and the adsorption was monitored by the methylene blue colorimetric method with the absorbance measured at $664 \mathrm{~nm}[32,33]$.

Solution $\mathrm{pH}$ was constant during the reaction, as measured before the start and after the completion of the reaction by an Orion 420A pH meter after 2-point calibration. Dissolved oxygen was analyzed using the $\mathrm{HACH}$ dissolved oxygen test kit (HACH Company, Loveland, $\mathrm{CO}$ ) in order to evaluate how completely the oxygen was removed by $\mathrm{N}_{2}$ purging. The dissolved oxygen in borate buffer after purging with $\mathrm{N}_{2}$ was less than the method detection limit of $6.3 \mu \mathrm{M}$. Dissolved oxygen was approximately $63 \mu \mathrm{M}$ before purging with $\mathrm{N}_{2}$.

\section{Results \\ Rates of $\mathrm{Cr}(\mathrm{VI})$ reduction by sulfide in the presence of various minerals}

Three clay minerals (illite, kaolinite and montmorillonite) and three metal oxides $\left(\mathrm{Al}_{2} \mathrm{O}_{3}, \mathrm{SiO}_{2}\right.$ and $\left.\mathrm{TiO}_{2}\right)$ were selected to assess the effect of minerals on the $\operatorname{Cr}(\mathrm{VI})$ reduction at $\mathrm{pH}$ 7.87. Initial concentrations of $\mathrm{Cr}(\mathrm{VI})$ and sulfide were 40 and $800 \mu \mathrm{M}$, respectively. Since sulfide concentration was at least 20 times as much as that of $\mathrm{Cr}(\mathrm{VI})$ during the reaction, a pseudo-first order condition was maintained with respect to $[\mathrm{Cr}(\mathrm{VI})]$. Kinetic data, presented as the $\ln [\mathrm{Cr}(\mathrm{VI})]$ v.s. time plots in Figure 1, however, did not follow the first order kinetics in most systems for the whole time period. In the control without any mineral, the line appears linear in the initial 40 minutes but curved downward, suggesting that the reaction was accelerated at the later stage of the reaction. This is consistent with the observation reported by Lan et al. [21]. The impact of minerals on $\mathrm{Cr}(\mathrm{VI})$ reduction could be assessed by comparing the rates between the systems containing a mineral and the control. As indicated by Figure 1, the tested minerals could be classified into three groups according to their effects on $\mathrm{Cr}(\mathrm{VI})$ reduction. Group 1 consisted of illite, which significantly accelerated $\mathrm{Cr}(\mathrm{VI})$ reduction. The time to complete the reaction was about $50 \%$ that of the control. The $\ln [\mathrm{Cr}(\mathrm{VI})]$ v.s. time plot was not linear throughout the whole time period but curved downward, suggesting the presence of additional pathways that might have catalyzed the reaction. Group 2 mineral includes $\mathrm{Al}_{2} \mathrm{O}_{3}$, which has no observed effect when compared to the control. Also the $\ln [\mathrm{Cr}(\mathrm{VI})]$ v.s. $\mathrm{t}$ plot was linear initially and then curved down. Group 3 minerals consisted of kaolinite, montmorillonite, $\mathrm{SiO}_{2}$ and $\mathrm{TiO}_{2}$, all of which inhibited $\mathrm{Cr}(\mathrm{VI})$ reduction by sulfide when compared to the control. Better linear trends in In $[\mathrm{Cr}(\mathrm{VI})]$ v.s. time plots were observed through the reactions for montmorillonite, $\mathrm{SiO}_{2}$, and $\mathrm{TiO}_{2}$, although $\mathrm{ln}$ $[\mathrm{Cr}(\mathrm{VI})]$ v.s t plots curved down too at the later stage of the reaction. For the system with kaolinite, no late stage acceleration was observed during the whole experimental time period.

\section{Effects of $\mathrm{pH}$}

$\mathrm{Cr}(\mathrm{VI})$ reduction by sulfide in the systems with illite and kaolinite $(3.0 \mathrm{~g} / \mathrm{L}$ solid loading) was examined from $\mathrm{pH}$ 7.67 to 9.07 in comparison with the mineral-free control. From the ln $[\mathrm{Cr}(\mathrm{VI})]$ v.s. time plots in Figure 2(a-f), we observed that: (1) rates of $\mathrm{Cr}(\mathrm{VI})$ reduction by sulfide followed this order: illite $>$ control $>$ kaolinite; (2) in the illite suspension and in the control, the overall reaction was characterized by a slow initial reaction step, followed by a fast one; (3) in the kaolinite suspension, all plots of 
$\ln [\mathrm{Cr}(\mathrm{VI})]$ versus time were linear; and (4) reaction rates were increased significantly with decreasing $\mathrm{pH}$ from 9.07 to 7.67 for all systems, with and without minerals. When only the initial linear sections of $\ln [\mathrm{Cr}(\mathrm{VI})]$ v.s. $t$ plots were examined in the system with illite and in the control, prior to the points of downward curvature where about $35 \%$ to $50 \%$ (or about 15 to $20 \mu \mathrm{M}$ ) of the initial $\mathrm{Cr}(\mathrm{VI})$ was reduced, we found that the observed rate constants were almost the same as those in the kaolinite suspension.

\section{Uptake of $\mathrm{Cr}(\mathrm{VI})$ and Sulfide}

Since the impact of minerals on $\mathrm{Cr}(\mathrm{VI})$ reduction could potentially be due to the sorption of reactants on the surfaces, we measured the sorption of both $\mathrm{Cr}(\mathrm{VI})$ and sulfide in separate batch systems at $\mathrm{pH} 7.87$ as a function of time for $120 \mathrm{~min}$. No detectable sorption of $\mathrm{Cr}(\mathrm{VI})$ was observed on the surfaces of illite or kaolinite minerals (3 $\mathrm{g} / \mathrm{L})$, as indicated by almost the same $\mathrm{Cr}(\mathrm{VI})$ concentration in the filtrate at the initial concentration of $40 \mu \mathrm{M}$. This result is not surprising because: (1) a much high concentration of borate buffer $(0.10 \mathrm{M})$ may out-compete $\mathrm{Cr}(\mathrm{VI})(40 \mathrm{mM})$ for surface sites; and (2) the surfaces of illite $\left(\mathrm{pH}_{\mathrm{pzc}}=4.5-5.0\right)$ and kaolinite $\left(\mathrm{pH}_{\mathrm{pzc}}=3.5\right)$ were negatively charged at $\mathrm{pH} 7.87$, discouraging sorption of negatively charged $\mathrm{Cr}_{2} \mathrm{O}_{7}{ }^{2-} / \mathrm{CrO}_{4}{ }^{2-}$. The observation was in agreement with results reported by Buerge ang Hug [25]. Also, no significant sorption of sulfide on kaolinite was observed at an initial sulfide concentration of 800 $\mu \mathrm{M}$. However, approximately $13 \%$ of sulfide (i.e., $104 \mu \mathrm{M}$ out of the original $800 \mu \mathrm{M}$ ) was lost in the system with 3.0 $\mathrm{g} / \mathrm{L}$ of illite within $20 \mathrm{~min}$, and stabilized afterward during the 120 min of testing period. The exact mechanism for the loss of sulfide was unclear; possible explanations included sorption on the mineral surfaces, precipitation as iron sulfide, and oxidation.

\section{$\mathrm{Fe}$ (II) sorbed onto illite}

When illite exposed to the buffered aqueous solution at $\mathrm{pH} 8.27$, we found the adsorbed amount of $\mathrm{Fe}(\mathrm{II})$ on illite $(3 \mathrm{~g} / \mathrm{L})$ was approximately $7.0 \mu \mathrm{M}$. The amount did not increase with time during a testing period of $90 \mathrm{~min}$ in this control. In the presence of $800 \mu \mathrm{M}$ sulfide, the adsorbed $\mathrm{Fe}(\mathrm{II})$ was increased by $4.0 \mu \mathrm{M}$ in the initial period ( $<30 \mathrm{~min}$ ) over the control, and there was little change afterwards. This additional $4.0 \mu \mathrm{M}$ of sorbed Fe(II) was small compared to the sulfide lost from the solution (104 mM) under comparable conditions. When $50 \mu \mathrm{M}$ of elemental sulfur was also added, another 1.5 to $2.0 \mu \mathrm{M}$ of sorbed $\mathrm{Fe}(\mathrm{II})$ was produced. Formation of polysulfides was expected when elemental sulfur and high concentration of sulfide were present. Polysulfides probably demonstrated higher reactivity towards reduction of structural $\mathrm{Fe}(\mathrm{III})$ in the illite, resulting in a slight increase in the sorbed amount of $\mathrm{Fe}(\mathrm{II})$ on the surfaces. In the experiments, there was no dissolved $\mathrm{Fe}(\mathrm{II})$ detected in the fil- trate. This is expected because at this alkaline $\mathrm{pH}(8.27)$, $\mathrm{Fe}(\mathrm{II})$ could be strongly adsorbed onto the surface of illite or precipitated on mineral surfaces as insoluble species.

\section{Effect of $\mathrm{Fe}(\mathrm{II})$ on the reaction}

To diagnose whether $\mathrm{Fe}(\mathrm{II})$ associated with illite could have an impact on $\mathrm{Cr}(\mathrm{VI})$ reduction by sulfide, experiments were conducted in the homogenous system spiked with $5.0 \mu \mathrm{M}$ ferrous chloride and the heterogeneous system with $3.0 \mathrm{~g} / \mathrm{L}$ of illite. As shown in Figure 3, rates of $\mathrm{Cr}(\mathrm{VI})$ reduction in the systems with ferrous iron and illite were comparable, with a slow initial rate but being accelerated at the later stage of the reaction. In contrast, direct $\mathrm{Cr}(\mathrm{VI})$ reduction by sulfide in the control test was much slower and showed a linear $\ln [\mathrm{Cr}(\mathrm{VI})]$ v.s. t plot within the whole experimental period. In the homogeneous system, the spiked $\mathrm{Fe}(\mathrm{II})$ apparently served as a catalyst for the reaction, i.e., $\mathrm{Cr}(\mathrm{VI})$ was reduced by $\mathrm{Fe}(\mathrm{II})$ to form $\mathrm{Fe}(\mathrm{III})$, which was then reduced by sulfide to regenerate $\mathrm{Fe}(\mathrm{II})$, enhancing the overall rate of $\mathrm{Cr}(\mathrm{VI})$ reduction. The fraction of $\mathrm{Cr}(\mathrm{VI})$ directly reduced by the initially added $\mathrm{Fe}(\mathrm{II})$ would not be significant because the spiked amount $(5.0 \mu \mathrm{M})$ was much less than the total amount of $\mathrm{Cr}(\mathrm{VI})$ $(40 \mu \mathrm{M})$ and it took three moles of $\mathrm{Fe}(\mathrm{II})$ to reduce one mole of $\mathrm{Cr}(\mathrm{VI})$. To understand if the sorbed iron on the illite surfaces played a similar role in the observed catalytic effect of illite, we conducted a set of experiments with illite in the presence of phenanthroline, a strong complexation agent for $\mathrm{Fe}(\mathrm{II})$. We hypothesized that if the sorbed iron on illite was responsible for the rate acceleration in the illite suspension, adding phenanthroline would decrease rate of $\mathrm{Cr}(\mathrm{VI})$ reduction because it formed strong complexes with $\mathrm{Fe}(\mathrm{II})$, known to inhibit $\mathrm{Cr}(\mathrm{VI})$ reduction in soils [34]. The effect of phenanthroline on $\mathrm{Cr}(\mathrm{VI})$ reduction in the homogeneous system was assessed in parallel as a control. The results, also presented in Figure

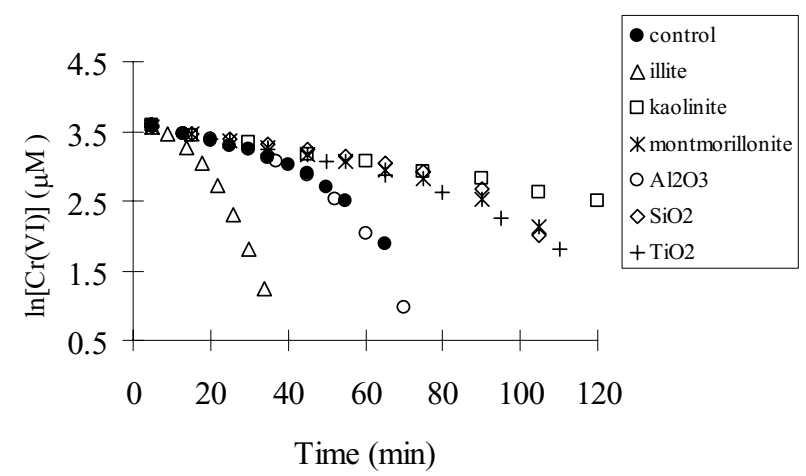

Figure I

Effects of various minerals on $\mathrm{Cr}(\mathrm{VI})$ reduction by sulfide at $\mathrm{pH}$ 7.87. Initial concentrations were $40 \mu \mathrm{M}$ for $\mathrm{Cr}(\mathrm{VI}), 800$ $\mu \mathrm{M}$ for sulfide, $5.00 \mathrm{~g} / \mathrm{L}$ for solid mineral when present. 

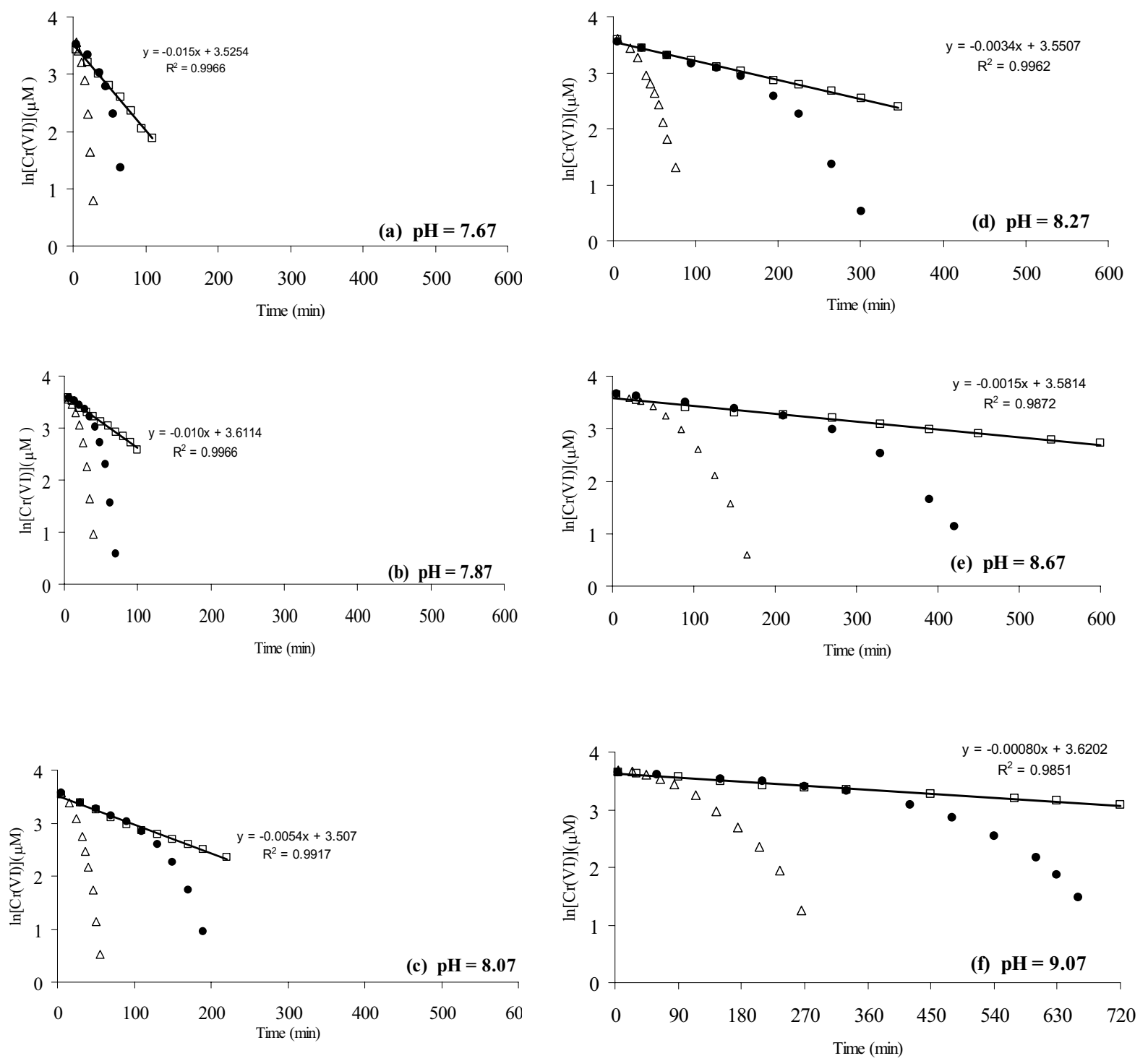

Triangle $(\Delta)$--- with $3.0 \mathrm{~g} / \mathrm{L}$ of illite; Square $(\square)$--- with $3.0 \mathrm{~g} / \mathrm{L}$ of kaolinite; Dot $(\bullet)$--- control.

\section{Figure 2}

Plots of $\ln [\mathrm{Cr}(\mathrm{VI})]$ vs. time show that the overall rate of $\mathrm{Cr}(\mathrm{VI})$ reduction is high with illite, low with kaolinite, and in the middle in the control without any mineral; and reaction rates decrease with increasing $\mathrm{pH}$ from $\mathrm{pH} 7.67$ to $\mathrm{pH} 9.07$. The initial concentrations of $\mathrm{Cr}(\mathrm{VI})$ and sulfide were $40 \mu \mathrm{M}$ and $800 \mu \mathrm{M}$, respectively.

3, demonstrated that phenanthroline completely neutralized the effect of illite on the reduction of $\mathrm{Cr}(\mathrm{VI})$, although it had no effect on the reaction in the homogeneous system. In the three systems: (1) illite and phenanthroline, (2) control (homogeneous) and (3) homogeneous system with phenanthroline, all $\ln [\mathrm{Cr}(\mathrm{VI})]$ v.s. time plots were linear with near identical slopes (rate constants), indicating the reaction order with respect to $\mathrm{Cr}(\mathrm{VI})$ was first order during the $160 \mathrm{~min}$ of experimental time period. These results suggested that the sorbed Fe(II) on illite must have catalyzed $\mathrm{Cr}(\mathrm{VI})$ reduction, and when 


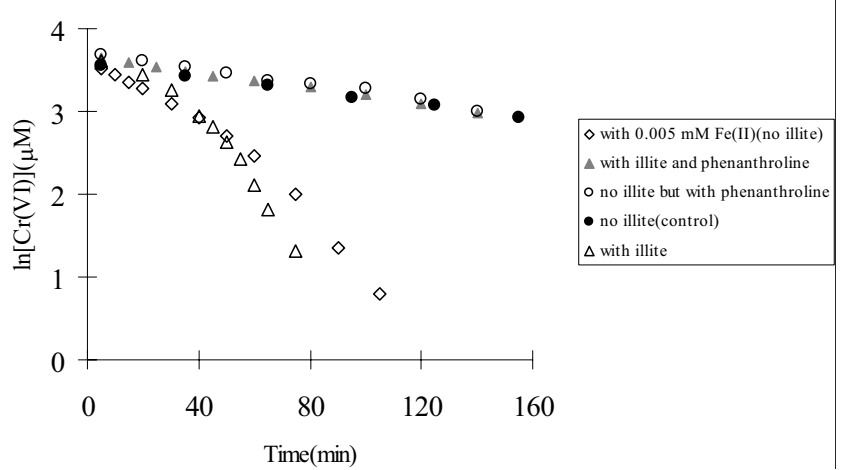

Figure 3

The presence of externally added ferrous iron and sorbed iron on illite $(3.0 \mathrm{~g} / \mathrm{L})$ increases rates of $\mathrm{Cr}(\mathrm{VI})$ reduction by sulfide as tested at $\mathrm{pH}$ 8.27. When phenanthroline, a strong $\mathrm{Fe}(\mathrm{II})$-complexation agent, is added, the effect of illite with sorbed iron on the $\mathrm{Cr}(\mathrm{VI})$ reduction reaction was neutralized.

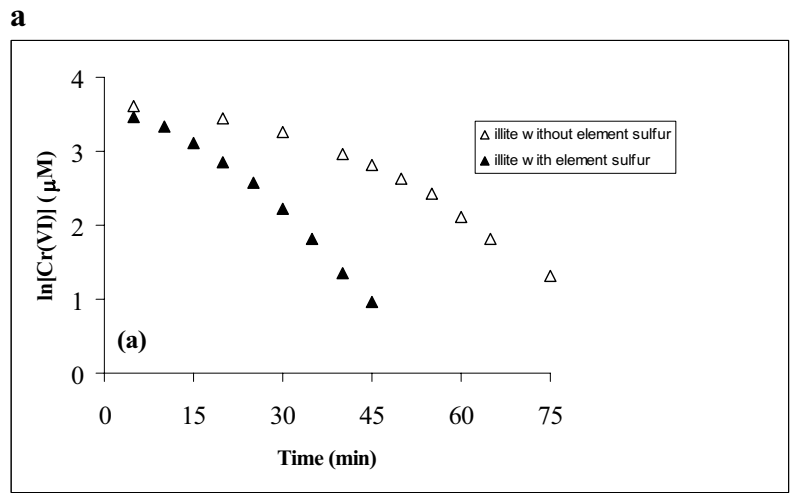

b

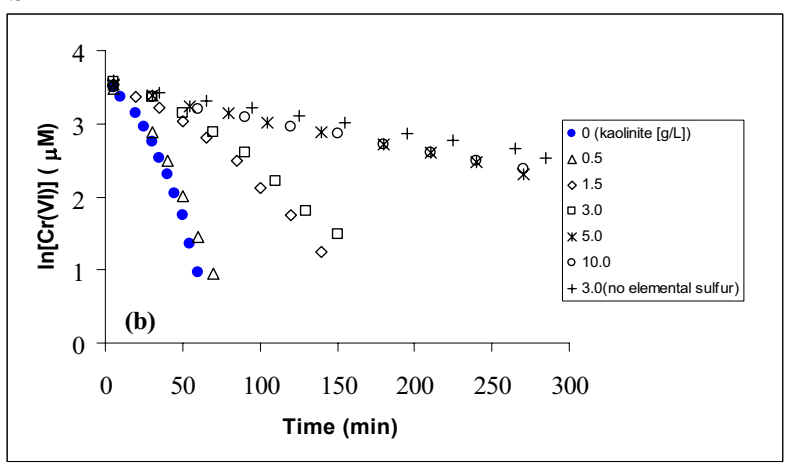

Figure 4

Effect of externally-added elemental sulfur on the reduction of $\mathrm{Cr}(\mathrm{VI})$ by sulfide at $\mathrm{pH}$ 8.27. (a) in $3.0 \mathrm{~g} / \mathrm{L}$ illite suspension, (b) in kaolinite suspensions with various solid loadings. it was coordinated with phenanthroline, the catalytic reactivity was inhibited.

\section{Effect of externally-added elemental sulfur}

As shown in Figure $4 \mathrm{a}, 50 \mu \mathrm{M}$ of externally-added elemental sulfur could accelerate the reduction of $\mathrm{Cr}(\mathrm{VI})$ by sulfide in the illite suspension $(3.0 \mathrm{~g} / \mathrm{L})$ : the time to near complete reduction of $40 \mu \mathrm{M} \mathrm{Cr}(\mathrm{VI})$ was shortened from 75 min to 45 min by adding elemental sulfur.

For kaolinite suspension, the effect of elemental sulfur was examined in a set of tests with kaolinite loadings increasing from 0 to $10.0 \mathrm{~g} / \mathrm{L}$ (Figure $4 \mathrm{~b}$ ). Significant rate enhancement by elemental sulfur was observed at low kaolinite loadings from $0.0-3.0 \mathrm{~g} / \mathrm{L}$. For example, with $3.0 \mathrm{~g} / \mathrm{L}$ of kaolinite, the time required to reduce $40 \mu \mathrm{M}$ of Cr (VI) was approximately $150 \mathrm{~min}$, which was much shorter than the rate without elemental sulfur where only $70 \%$ of the $\mathrm{Cr}(\mathrm{VI})$ was reduced within $300 \mathrm{~min}$. However, the effect of elemental sulfur was less pronounced when the amount of kaolinite was increased. At a $0.50 \mathrm{~g} / \mathrm{L}$ level, the effect of kaolinite was barely detectable; and when kaolinite was at or higher than $5.0 \mathrm{~g} / \mathrm{L}$, the plots of $\mathrm{ln}$ $[\mathrm{Cr}(\mathrm{VI})]$ v.s. time were almost the same as for the system without externally-added elemental sulfur. The observed rate constants in the two tests with $50 \mu \mathrm{M}$ of added elemental sulfur but also the highest kaolinite concentrations $\left(k_{\mathrm{obs}}=4.1 \times 10^{-3} \mathrm{~min}^{-1}\right)$ were very close to that in the suspension without added elemental sulfur $\left(k_{\mathrm{obs}}=3.5 \times\right.$ $10^{-3} \mathrm{~min}^{-1}$ ), indicating that the effect of externally-added elemental sulfur was neutralized by the high concentration of kaolinite.

\section{Effect of sulfide concentration}

Increasing sulfide concentration from 600 to $1400 \mu \mathrm{M}$ resulted in accelerated $\mathrm{Cr}(\mathrm{VI})$ reduction in the presence of kaolinite $(3.0 \mathrm{~g} / \mathrm{L})$ at $\mathrm{pH} 8.27$, as shown in Fig. 5. The $\mathrm{ln}$ $[\mathrm{Cr}(\mathrm{VI})]$ v.s. $t$ plots were all linear under the experimental conditions with $\mathrm{r}^{2}>0.99$ for all experiments.

\section{Discussion}

Previous studies $[20,21]$ have shown that the stoichiometry for the aqueous phase $\mathrm{Cr}(\mathrm{VI})$ reduction by sulfide is: $2 \mathrm{CrO}_{4}{ }^{2-}+3 \mathrm{HS}^{-}+7 \mathrm{H}^{+}=2 \mathrm{Cr}(\mathrm{OH})_{3}(\mathrm{~s})+3 \mathrm{~S}(\mathrm{~s})+2 \mathrm{H}_{2} \mathrm{O}$, under anoxic conditions. The presence of minerals as examined in the study is not expected to change the stoichiometry, but only the kinetics.

The examined minerals fall into three groups based on their effects on the rate of $\mathrm{Cr}(\mathrm{VI})$ reduction by sulfide: illite in Group 1 exhibits remarkable catalysis; $\mathrm{Al}_{2} \mathrm{O}_{3}$ in Group 2 shows no significantly effect in comparison with the homogeneous control; and $\mathrm{TiO}_{2}, \mathrm{SiO}_{2}$, kaolinite and montmorillonite, all in Group 3, inhibit $\mathrm{Cr}(\mathrm{VI})$ reduction to various degrees. Different effects demonstrated by these 


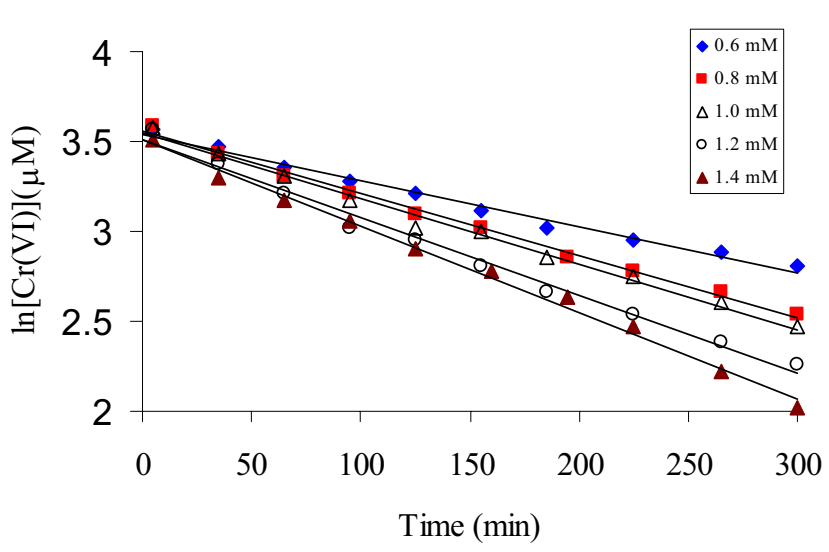

Figure 5

Effect of sulfide concentration on the reduction of $\mathrm{Cr}(\mathrm{VI})$ by sulfide at $\mathrm{pH} 8.27$ in $3.0 \mathrm{~g} / \mathrm{L}$ kaolinite suspension.

minerals can not be explained by their differences in specific surface area (SSA) as listed in Table 1. For example, illite has the lowest SSA among all tested minerals but can accelerate the reaction most dramatically. Other minerals with larger SSA such as kaolinite, montmorillonite, $\mathrm{Al}_{2} \mathrm{O}_{3}$ and $\mathrm{SiO}_{2}$ also show different effects on the $\mathrm{Cr}(\mathrm{VI})$ reduction reaction.

By comparing $\mathrm{Cr}(\mathrm{VI})$ concentration in the filtrate of illite and kaolinite suspensions with its initial concentration, we find insignificant sorption of $\mathrm{Cr}(\mathrm{VI})$ for either of these two minerals. In addition, the reduction rates of $\mathrm{Cr}(\mathrm{VI})$ by sulfide in these two suspensions are quite different. It seems significant adsorption of $\mathrm{Cr}(\mathrm{VI})$ may not be required for $\mathrm{Cr}(\mathrm{VI})$ reduction. As for sulfide, while a maximal $13 \%$ of initial sulfide is lost in the system with illite, probably due to sorption, kinetic of $\mathrm{Cr}(\mathrm{VI})$ reduction in the illite suspension with phenanthroline is almost identical to those in kaolinite suspension and in homogeneous system (Fig. 3 and 4b). Our unreported data show that phenanthroline does not influence sulfide adsorption on goethite, so it may not affect sulfide sorption on illite either. Therefore, the sorption of sulfide is also unlikely to be a key factor that could result in catalysis of $\mathrm{Cr}(\mathrm{VI})$ in the illite suspension. Instead, $\mathrm{Fe}(\mathrm{II}) / \mathrm{Fe}(\mathrm{III})$, likely coordinated with hydroxyl group in the tested $\mathrm{pH}$ range of 7.67 to 9.07 , must be involved in accelerating the reduction of $\mathrm{Cr}(\mathrm{VI})$ by sulfide in illite suspension. This agrees with the observations that (1) phenanthroline can block $\mathrm{Cr}(\mathrm{VI})$ reduction by sorbed $\mathrm{Fe}(\mathrm{II})$ through formation of very stable complex and (2) soluble ferrous iron addition to homogeneous systems greatly enhances rate of $\mathrm{Cr}(\mathrm{VI})$ reduction.
We have previously reported that the overall kinetics of $\mathrm{Cr}(\mathrm{VI})$ reduction by sulfide in the homogenous system can be expressed by the following empirical equation[21]:

$$
-\frac{d[\mathrm{Cr}(\mathrm{VI})]}{d t}=k_{1}[\mathrm{Cr}(\mathrm{VI})]\left[\mathrm{HS}^{-}\right]^{0.63}+k_{2}[\mathrm{Cr}(\mathrm{VI})][\equiv \mathrm{S}-\mathrm{SH}]^{0.57}
$$

Where the first term represents the reaction between aqueous $\mathrm{Cr}(\mathrm{VI})$ and sulfide, and the second term represents $\mathrm{Cr}(\mathrm{VI})$ reduction by polysulfide/sorbed sulfide on elemental sulfur nanoparticles. Considering that $\mathrm{Fe}(\mathrm{II})$ is involved in $\mathrm{Cr}(\mathrm{VI})$ reduction in the heterogeneous system, such as in illite suspension, and the reaction is first order with respect to both $\mathrm{Cr}(\mathrm{VI})$ and $\mathrm{Fe}(\mathrm{II})$ as reported by Buerge et al. [8,25], the empirical equation (1) could be modified to:

$-\frac{d[\mathrm{Cr}(\mathrm{VI})]}{d t}=k_{1}[\mathrm{Cr}(\mathrm{VI})]\left[\mathrm{HS}^{-}\right]^{0.63}+k_{2}[\mathrm{Cr}(\mathrm{VI})][\equiv \mathrm{S}-\mathrm{SH}]^{0.57}+k_{3}[\mathrm{Cr}(\mathrm{VI})][\mathrm{Fe}(\mathrm{II})]$

Since the concentrations of $\equiv \mathrm{S}-\mathrm{SH}$ and $\mathrm{Fe}$ (II) increase with time in the system with illite, rates of $\mathrm{Cr}(\mathrm{VI})$ reaction could be accelerated, which explains why the reaction does not follow a first order kinetics throughout the whole experimental duration, even though the sulfide concentration is maintained constant. It should be pointed that in the illite suspension with $\mathrm{pH}$ from 7.67 to 9.07 investigated in this study, FeS is likely the main species of Fe(II) as suggested by Patterson and Fendorf [24] and Morse et al. [35]. Nevertheless, freshly formed FeS can also quickly reacts with $\mathrm{Cr}(\mathrm{VI})[24]$, so delineation of exact $\mathrm{Fe}$ (II) species is not essential to understand $\mathrm{Cr}(\mathrm{VI})$ reduction by sulfide in our systems.

Considering that phenanthroline will block $\mathrm{Fe}(\mathrm{II})$ as a reductant and in the initial stage of the reaction, the effect of elemental sulfur product on the overall reaction is not important as reported by Lan et al. [21]. Equation (2) can thus be written as:

$$
-d[\mathrm{Cr}(\mathrm{VI})] / d t=k_{\mathrm{obs}}[\mathrm{Cr}(\mathrm{VI})]
$$

where $k_{\mathrm{obs}}=k_{1}$ [HS- $^{0.63}$. The overall reaction now becomes pseudo first order with respect to $\mathrm{Cr}(\mathrm{VI})$ under this condition. This agrees with our experimental observations that the plot of $\ln [\mathrm{Cr}(\mathrm{VI})]$ v.s. time is linear (with $\mathrm{r}^{2}=0.996$ ) within 150 min of reaction, when approximately $50 \%$ of initial Cr(VI) is reduced (Fig. 3). The rate constant $k_{\text {obs }}$ was $0.0047 \mathrm{~min}^{-1}$, very close to the $k_{\text {obs }}$ values of $0.0040 \mathrm{~min}^{-1}$ $\left(\mathrm{r}^{2}=0.992\right)$ and $0.0048 \mathrm{~min}^{-1}\left(\mathrm{r}^{2}=0.986\right)$ obtained from the homogeneous systems without and with phenanthroline, respectively. 
In this study, total amount of ferrous iron is low: with 5 $\mu \mathrm{M}$ spiked into the homogeneous system and $7.0 \mu \mathrm{M}$ of $\mathrm{Fe}(\mathrm{II})$ detected in the presence of illite. According to a $\mathrm{Cr}(\mathrm{VI}) / \mathrm{Fe}(\mathrm{II})$ molar ratio of $1: 3$ for the reaction, only about $1-2 \mu \mathrm{M}$ of $\mathrm{Cr}(\mathrm{VI})$ could be consumed by $\mathrm{Fe}(\mathrm{II})$, which is insignificant when compared to the initial $\mathrm{Cr}(\mathrm{VI})$ concentration of $40 \mu \mathrm{M}$. However, rates of $\mathrm{Cr}(\mathrm{VI})$ reduction by sulfide were significantly different with and without iron. It is therefore likely that $\mathrm{Fe}(\mathrm{II}) / \mathrm{Fe}(\mathrm{III})$ serves as an electron shuttle, mediating the electron transfer between $\mathrm{Cr}(\mathrm{VI})$ and sulfide as illustrated below:

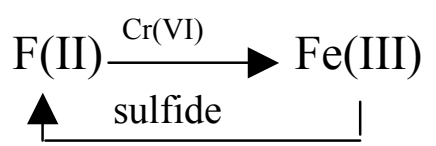

This interpretation is consistent with our experiments showing that $\mathrm{Cr}(\mathrm{VI})$ reduction by $\mathrm{Fe}(\mathrm{II})$ is much faster than the reduction of $\mathrm{Cr}(\mathrm{VI})$ by sulfide at $\mathrm{pH} 7-9$, as well as the results reported in the literature[36].

Kaolinite is one of the minerals that inhibit $\mathrm{Cr}(\mathrm{VI})$ reduction by sulfide. In the presence of kaolinite, the kinetic results $\left(k_{\text {obs }}\right)$ obtained at $\mathrm{pH}$ ranging from 7.67 to 9.07 are all close to those in the homogeneous system (Fig. 2a-f) at the initial stage of the reaction, when the elemental sulfur is expected to exert no effect on the reaction. It is likely that the elemental sulfur produced from the reaction is sequestered by kaolinite, so the catalytic effect of elemental sulfur is eliminated. Under this circumstance, the second term in Equation (1) is negligible and a pseudo-first order dependence on $\mathrm{Cr}(\mathrm{VI})$ should be observed. This is exactly what we have measured in the experiments (Figure $5)$.

When the effect of $\mathrm{pH}$ is examined on $\mathrm{Cr}(\mathrm{VI})$ reduction in the kaolinite suspension, a generic rate equation can be written as:

$$
-d[\mathrm{Cr}(\mathrm{VI})] / d t=k[\mathrm{Cr}(\mathrm{VI})]\left[\mathrm{HS}^{-}\right]^{\mathrm{a}}\left[\mathrm{H}^{+}\right]^{\mathrm{b}}
$$

If sulfide concentration and solution $\mathrm{pH}$ are kept constant, Equation (5) is simplified to Equation (3) again, with $k_{\text {obs }}=k\left[\mathrm{HS}^{-}\right]^{\mathrm{a}}\left[\mathrm{H}^{+}\right]^{\mathrm{b}}$. Using the experimental results in Figure 2 under various $\mathrm{pH}$ values, we could evaluate the $\mathrm{pH}$ dependence of the reaction in the kaolinite system by the relationship: $\ln k_{\mathrm{obs}}=\ln k$ [HS-] ${ }^{\mathrm{a}}-\mathrm{b} \mathrm{pH}=K-\mathrm{b} \mathrm{pH}$. As shown by Figure 6 , the $\ln k_{\text {obs }}$ v.s. pH plots for the kaolinite suspension and the initial stage of the homogeneous reaction are linear, with the slopes of -2.13 and -2.05 , respectively. The result suggests that the reaction order with respect to $\mathrm{H}^{+}$is almost 2, higher than the 1 reported by Pettine et al. [19].

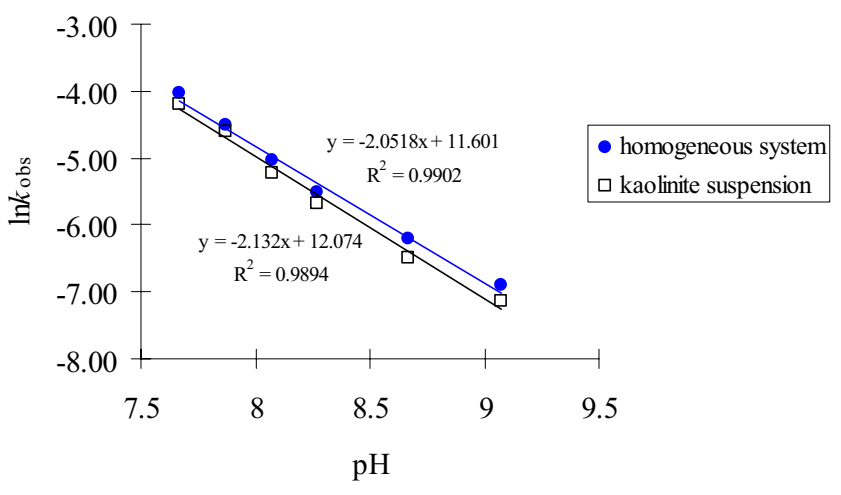

Figure 6

In $k_{\text {obs }}$ as a function of $\mathrm{pH}$ in $3 \mathrm{~g} / \mathrm{L}$ kaolinite suspension and homogeneous system. The $k_{\text {obs }}$ in the homogeneous system is for the initial stage of the reaction only, when approximately 35 to $50 \%$ of initial $\mathrm{Cr}(\mathrm{VI})$ was consumed.

At constant $\mathrm{pH}$ of 8.27 , the rate constant $\left(k_{\text {obs }}\right)$ increased with increasing sulfide concentration, with a slope of 0.70 in the $\ln k_{\mathrm{obs}}$ versus $\ln \left[\mathrm{H}_{2} \mathrm{~S}\right]$ plot (Figure 7). A fractional reaction order of 0.70 with respect to total sulfide in the kaolinite suspension is close to the reaction of of 0.63 in the homogeneous system [21], but is lower than the reaction orders reported by Pettine et al. [6,19] and Kim et al. [20].

The effect of externally added elemental sulfur $(50 \mu \mathrm{M})$ on $\mathrm{Cr}(\mathrm{VI})$ reduction in the kaolinite suspension is strongly dependent on kaolinite loading. $\mathrm{Cr}(\mathrm{VI})$ reduction is enhanced by elemental sulfur at kaolinite loading less than $3.0 \mathrm{~g} / \mathrm{L}$ (see Fig. 4b). At $0.5 \mathrm{~g} / \mathrm{L}$ kaolinite, the rate is almost the same as that in the control without kaolinite. When kaolinite concentration is increased to $5.0 \mathrm{~g} / \mathrm{L}$ and higher, however, the catalytic effect of elemental sulfur disappears. It seems the externally added elemental sulfur

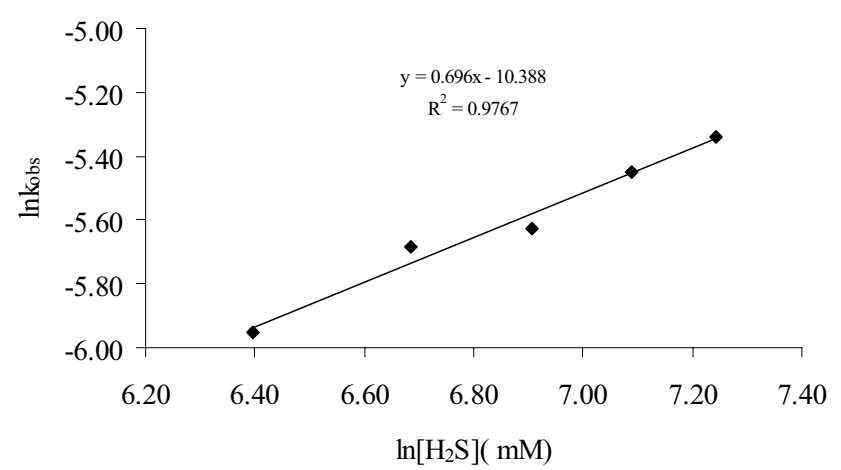

Figure 7

Values of $\ln k_{\text {obs }}$ as a function of $\ln \left[\mathrm{HS}^{-}\right]_{\text {total }}$ at $\mathrm{pH} 8.27$ and in $3.0 \mathrm{~g} / \mathrm{L}$ kaolinite suspension. 
is also sequestered by kaolinite, eliminating its catalytic effect. From Figure 1, we know that $3.0 \mathrm{~g} / \mathrm{L}$ of kaolinite can eliminate the catalytic effect of elemental sulfur produced from reaction with $40 \mu \mathrm{M} \mathrm{Cr}(\mathrm{VI})$, which is $60 \mu \mathrm{M}$. When an additional $50 \mu \mathrm{M}$ of elemental sulfur is added externally, $5.0 \mathrm{~g} / \mathrm{L}$ or more kaolinite is needed to eliminate the effect of elemental sulfur, which is consistent with the observation shown in Fig. $4 \mathrm{~b}$.

No detailed experiment was conducted to examine the inhibitive effect of montmorillonite, $\mathrm{TiO}_{2}$ and $\mathrm{SiO}_{2}$ on the reduction of $\mathrm{Cr}(\mathrm{VI})$ by sulfide. It is expected that elemental sulfur is similarly sequestered by montmorillonite, $\mathrm{SiO}_{2}$, and $\mathrm{Al}_{2} \mathrm{O}_{3}$, losing its catalytic reactivity.

\section{Acknowledgements}

This study was supported by the U.S. Department of Energy through the Environmental Remediation Science Program (Grant No. DE-FG0799ER I50II and DE-FG02-03ER63616). Partial support by the National Natural Science Foundation of China (Grant No. 40671089) was also greatly appreciated.

\section{References}

I. Deng B: Chromium(VI) Reduction by Naturally-Occurring Organic Compounds: Direct and Surface-Catalyzed Reactions Ph.D. Dissertation, Johns Hopkins University, Baltimore, MD, USA; 1995.

2. James BR: The challenge of remediating chromium-contaminated soil. Environmental Science and Technology 1996, 30(6):248A-25IA

3. Blowes DW, Ptacek CJ, Jambor JL: In-Situ Remediation of Chromate Contaminated Groundwater Using Permeable Reactive Walls. Environmental Science \& Technology 1997, 31:3348-3357.

4. Eary LE, Rai D: Chromate Removal from Aqueous Wastes by Reduction with Ferrous Ion. Environmental Science \& Technology 1988, 22:972-977.

5. Sedlak DL, Chan PG: Reduction of Hexavalent Chromium (VI) by Ferrous Iron. Geochim Cosmochim Acta 1997, 61:2185-2192.

6. Pettine M, D'Ottone L, Campanella L, Millero FJ, Passino R: The Reduction of Chromium (VI) by Iron (II) in Aqueous Solution. Geochimica et Cosmochimica Acta 1998, 62:1509-1519.

7. Buerge IJ, Hug SJ: Kinetics and pH Dependence of Chromium (VI) Reduction by Iron (II). Environmental Science \& Technology 1997, 31: | 426-1432.

8. Buerge IJ, Hug SJ: Influence of Organic Ligands on Chromium (VI) Reduction by Iron (II). Environmental Science \& Technology 1998, 32:2092-2099.

9. Seaman JC, Bertsch PM, Schwallie L: In Situ Cr (VI) Reduction within Coarse-Textured, Oxide-Coated Soil and Aquifer Systems Using Fe (II) Solution. Environmental Science \& Technology 1999, 33:938-944.

10. Fruchter J: In Situ Treatment of Chromium-contaminated Groundwater. Environmental Science \& Technology 2002, 36:464A-472A.

II. Bond D, Fendorf S: Kinetics and Structural Constraints of Chromate Reduction by Green Rusts. Environmental Science \& Technology 2003, 37:2750-2757.

12. James B, Bartlett RJ: Behavior of Chromium in Soils. VI. Interactions Between Oxidation-Reduction and Organic Complexation. J Environ Qual 1983, 12:177-181.

13. Wittbrodt PR, Palmer CD: Reduction of $\mathrm{Cr}(\mathrm{VI})$ in the Presence of Excess of Soil Fulvic Acid. Environmental Science \& Technology 1995, 29:255-263.

14. Goodgame D-L, Hayman PB: Formation of Water-soluble Chromium(V) by the Interaction of Humic Acid and the Carcinogen Chromium(VI). Inorganica Chimica Acta 1984, 9 I: I I3-I I 5.

15. Thornton EC, Amonette JE: Gas Treatment of Cr(VI)-contaminated Sediment Samples from the North 60's Pits of the Chemical Waste Landfill; PNNL-I I 634 Pacific Northwest National Laboratory: Richland, WA; 1997.
16. Thornton EC, Amonette JE: Hydrogen Sulfide Gas Treatment of $\mathrm{Cr}$ (VI)-Contaminated Sediment Samples from a PlatingWaste Disposal Site. Implication for in-Situ Remediation. Environmental Science \& Technology 1999, 33:4096-4I01.

17. ASME: Technical Peer Review Report in Assessment of Technologies Supported by the Office of Science and Technology Department of Energy The American Society of Mechanical Engineers; 1999:257-264.

18. Cantrell KJ, Yabusaki SB, Engelhard MH, Mitroshkov AV, Thornton EC: Oxidation of $\mathbf{H}_{2} \mathbf{S}$ by Iron Oxides in Unsaturated Conditions. Environ Sci Technology 2003, 37:2192-2199.

19. Pettine M, Millero FJ, Passino R: Reduction of Chromium (VI) with Hydrogen Sulfide in NaCl Media. Marine Chemistry 1994 , 46:335-344

20. Kim C, Zhou Q, Deng B, Thornton EC, Xu H: Chromium (VI) Reduction by Hydrogen Sulfide in Aqueous Media: Stoichiometry and Kinetics. Environmental Science \& Technology 200I, 35:2219-2225.

21. Lan Y, Deng B, Kim C, Thornton EC, Xu H: Catalysis of Elemental Sulfur Nanoparticles on Chromium (VI) Reduction by Sulfide under Anaerobic Conditions. Environmental Science \& Technology 2005, 39:2087-2094.

22. Hua B, Deng B: Influences of Water Vapor on $\mathrm{Cr}(\mathrm{VI})$ Reduction by Gaseous Hydrogen Sulfide. Environmental Science \& Technology 2003, 37:477| I-4777.

23. Eary LE, Rai $D$ : Kinetics of Chromate Reduction by Ferrous Ions Derived From Hematite and Biotite at $25^{\circ} \mathrm{C}$. Am J Sci 1989, 289: $180-213$

24. Patterson RR, Fendorf S: Reduction of Hexavalent Chromium by Amorphous Iron Sulfide. Environmental Science \& Technology 1997, 3 I:2039-2044.

25. Buerge IJ, Hug S): Influence of Mineral Surfaces on Chromium (VI) Reduction by Iron (II). Environmental Science \& Technology 1999, 33:4285-4291.

26. Deng B, Stone AT: Surface-Catalyzed Chromium (VI) Reduction: The $\mathrm{TiO}_{2}-$ Mandelic Acid System. Environmental Science \& Technology 1996, 30:463-472.

27. Deng B, Stone AT: Surface-Catalyzed Chromium(VI) Reduction: Reactivity Comparisons among Different Organic Reductants and Different Catalytic Surfaces. Environmental Science \& Technology 1996, 30:2484-2494.

28. Stumn W, Morgan JJ: Aquatic Chemistry New York: Wiley-Interscience; 1996.

29. Zhachara JM, Davis JA, Liu C, McKinley JP, Qafoku N, Wellman DM, Yabusaki SB: Uranium Geochemistry in Vadose Zone and Aquifer Sediments from the 300 Area Uranium Plum Pacific Northwest National Laboratory report PNNL-I5 I2I; 2005

30. Amonette JE, Workman AJ, Kennedy DW, Fruchter JS, Gorby YA: Dechlorination of Carbon Tetrachloride by Fe(II) Associated with Goethithe. Environmental Science \& Technology 2000, 34:4606-46I3.

3I. Lovley DR, Philips E-P: Availability of Trivalent Iron for Microbial Reduction in Bottom Sediments of the Freshwater Tidal Potomac River. Appl And Environ Microbiol 1986, 52:75I-757.

32. APHA; AWWA; WPCF: Standard Methods for the Examination of Water and Wastewater 20th edition. American Public Health Association: Washington, D. C; 1998.

33. Allen HE, Fu G, Deng B: Analysis of Acid Volatile Sulfide (AVS) and Simultaneously Extracted Metals (SEM) for the Estimation of Potential Toxicity in Aquatic Sediments. Environ Toxicol Chem 1993, I 2: |44|-|453.

34. Anderson LD, Kent DB, Davis JA: Batch Experiments Characterizing the Reduction of $\mathrm{Cr}(\mathrm{VI})$ Using Suboxic Material from a Mildly Reducing Sand and Gravel Aquifer. Environmental Science \& Technology 1994, 28: 178-185.

35. Morse JW, Millero FJ, Cornwell JC, Rickard D: The Chemistry of the Hydrogen Sulfide and Iron Sulfide Systems in Natural Waters. Earth Sci Rev 1987, 24:I.

36. Lan Y, Yang J, Deng B: Catalysis of Dissolved and Adsorbed Iron in Soil Suspension for Chromium(VI) Reduction by Sulfide. Pedosphere 2006, 16(5):572-578. 